ISSN 1420-3049

www.mdpi.com/journal/molecules

Article

\title{
Antioxidant Properties of Marrubium peregrinum L. (Lamiaceae) Essential Oil
}

\author{
Biljana Kaurinovic ${ }^{1, *}$, Sanja Vlaisavljevic ${ }^{1}$, Mira Popovic ${ }^{1}$, Djendji Vastag ${ }^{1}$ and Maja \\ Djurendic-Brenesel $^{2}$
}

1 Department of Chemistry, Faculty of Science, University of Novi Sad, Trg Dositeja Obradovica 3, 21000 Novi Sad, Serbia

2 Clinical Center of Vojvodina, Department for Forensic Medicine, Hajduk Veljkova 7-9, 21000 Novi Sad, Serbia

* Author to whom correspondence should be addressed; E-Mail: biljana.kaurinovic@dh.uns.ac.rs; Tel.: +381214852770; Fax: +38121454065.

Received: 25 June 2010; in revised form: 25 August 2010 / Accepted: 27 August 2010 /

Published: 27 August 2010

\begin{abstract}
The antioxidant activity of Marrubium peregrinum essential oil, collected from three different locations [Backo Gradiste - Rimski Sanac (No.1), Novi Knezevac (No.2) and Senta (No.3)] was evaluated as free radical scavenging capacity (RSC), together with inhibition on xanthine-oxidase and effects on lipid peroxidation (LP). RSC was assessed measuring the scavenging activity of the essential oils on 2,2-diphenyl-1-picrylhydrazyl $\left(\mathrm{DPPH}^{\bullet}\right)$, super oxide anion $\left(\mathrm{O}_{2}^{\bullet-}\right)$, nitric-oxide $\left(\mathrm{NO}^{\bullet}\right)$ and hydroxyl $\left(\mathrm{OH}^{\bullet}\right)$ radicals. The activities of xanthine-oxidase (XOD) was determined by the nitrite method. Effects on LP were evaluated by following the activities of essential oils in the $\mathrm{Fe}^{2+}$ /ascorbate induction system. Experimental results indicate that the essential oil of $M$. peregrinum from Senta (No.3) exhibited the strongest inhibitory effect, as the $\mathrm{IC}_{50}$ value was achieved with the lowest concentration. The same result was obtained in investigation of influence of essential oil on XOD and LP. The chemical profile of essential oil was evaluated by the means of gas chromatography-mass spectrometry (GC-MS). According to the analysis, the most powerful scavenging compounds were sesquiterpene hydrocarbons ( $\beta$-caryophyllene, bicyclogermacrene and germacrene-D) and oxygenated sesquiterpenes (spathulenol and caryophyllene oxide).
\end{abstract}


Keywords: Marrubium peregrinum L.; essential oils; GC-MC; antioxidant activity; lipid peroxidation

\section{Introduction}

For centuries, aromatic herbs and spices have been added to different foods to improve the flavor and organoleptic properties. The use of aromatic plants and spices in phytotherapy is mostly related to different activities of their essential oils, such as antimicrobial, spasmolytic, carminative, hepatoprotective, antiviral, anticarcinogenic activities, etc. [1,2]. Furthermore, many studies point to strong antioxidant activities of aromatic plants and their essential oils [3-5]. Antioxidant activities are also confirmed for most of the phenolic compounds present in different spices and herbs $[3,6]$.

The enlarged Lamiaceae family contains 233 to 263 genera and 6,900 to 7,200 species. The genus Marrubium L. comprises approximately 30 species indigenous in Europe, the Mediterranean area and Asia [7]. The chemical composition of $M$. peregrinum has been extensively studied. $M$. peregrinum leaves contain no more than $0.1 \%$ of essential oil, which is of complex and variable composition [8]. Dominant monoterpenes are: $\alpha$-pinene, sabinene, limonene, camphene and $\alpha$-terpinolene. In a Greek sample, $\beta$-phellandrene, epi-bicyclosesquiphellandrene and bicyclogermacrene proved to be the major compounds [9], whereas the essential oil of a sample from Central Europe was rich in $\beta$-caryophyllene and its oxide, bicyclogermacrene and germacrene D [10]. In previous phytochemical investigations on $M$. peregrinum, different groups of chemicals were isolated: flavones (apigenin and luteolin) [11], flavonols (kaempferol) [12], glycosylated flavonoids, caffeic acid derivatives [13], and four diterpenoids (peregrinin, peregrinol, marrubiin and premarrubiin) [14,15].

As a medicinal plant, $M$. peregrinum has been employed against vascular diseases (antihypertensive, antispasmolitic). El Bardai et al. [16] have established that marrubenol inhibits contraction of rat arteries by blocking L-type calcium $\left(\mathrm{Ca}^{2+}\right)$ channels in smooth muscle cells. Also, one of the flavonoids present in $M$. peregrinum, apigenin, was shown to express strong antioxidant effects, increasing the activities of antioxidant enzymes and, related to that, decreasing the oxidative damage to tissues [17].

The aim of this research was to study the chemical profile of essential oil of Marrubium peregrinum and the antioxidant activity in vitro, to assess their potential capacity as scavengers of free radicals (DPPH, $\mathrm{O}_{2}{ }^{-}$, $\mathrm{NO}$ and $\mathrm{OH}$ radicals) and as inhibitors of xanthine-oxidase and lipid peroxidation. The chemical characterization of the investigated essential oils was performed by gas chromatographymass spectrometry (GC-MS).

\section{Results and Discussion}

The content of essential oils expressed in percentages was as follows: Marrubium peregrinum (Backo Gradiste - Rimski Sanac; No.1), 0.11\%; Marrubium peregrinum (Novi Knezevac; No.2), 0.09\%; and Marrubium peregrinum (Senta; No.3), 0.14\%. The results are consistent with the literature data, and a small deviation in the amount of essential oil from plants collected from the three different localities can be explained by the fact that a number of factors affects the yield of essential oils: time of 
collection of the plant material, maturity of plants, method of oil isolation, the herb drying method, material fermentation, agroecological conditions, etc.. In addition, the yield of essential oil varies with change of light intensity and medium in which the plant grows $[18,19]$.

Table 1. Chemical composition of Marrubium peregrinum essential oil.

\begin{tabular}{|c|c|c|c|c|c|}
\hline \multirow[b]{2}{*}{ Compounds } & \multirow[b]{2}{*}{$\mathbf{R} \mathbf{I}^{\mathbf{a}}$} & \multicolumn{3}{|c|}{ Percentage } & \multirow[b]{2}{*}{$\begin{array}{r}\begin{array}{r}\text { Identification } \\
\text { method }^{\mathrm{b}}\end{array} \\
\end{array}$} \\
\hline & & $\begin{array}{c}\text { M. peregrinum } \\
\text { (No. 1) }\end{array}$ & $\begin{array}{c}\text { M. peregrinum } \\
\text { (No. 2) }\end{array}$ & $\begin{array}{c}\text { M. peregrinum } \\
(\text { No. 3) }\end{array}$ & \\
\hline$\alpha$-pinene & 939 & 0.36 & 0.27 & 0.32 & RT GC MS \\
\hline camphene & 950 & 0.10 & 0.10 & 0.13 & $\mathrm{RT}^{*} \mathrm{MS}$ \\
\hline sabinene & 972 & - & 0.12 & 0.10 & RT GC MS \\
\hline 1-octen-3-ol & 976 & 4.88 & 5.08 & 2.94 & $\mathrm{RT}^{*} \mathrm{MS}$ \\
\hline$\beta$-pinene & 978 & 0.46 & 0.52 & 0.46 & RT GC MS \\
\hline limonene & 1030 & 0.98 & 1.12 & 1.20 & RT GC MS \\
\hline$\beta$-phellandrene & 1034 & 0.92 & 0.80 & 0.92 & $\mathrm{RT}^{*} \mathrm{MS}$ \\
\hline$\alpha$-terpinolene & 1090 & 0.38 & 0.44 & 0.50 & $\mathrm{RT}^{*} \mathrm{MS}$ \\
\hline linalool & 1100 & 0.20 & 0.27 & 0.25 & RT GC MS \\
\hline$\alpha$-thujone & 1104 & 2.12 & 2.31 & 3.26 & RT GC MS \\
\hline nonanal & 1105 & 0.28 & 0.52 & 0.28 & $\mathrm{RT}^{*} \mathrm{MS}$ \\
\hline$\beta$-thujone & 1104 & 1.46 & 1.28 & 1.71 & RT GC MS \\
\hline geijerene & 1150 & 3.21 & 4.02 & 3.70 & $\mathrm{RT}^{*} \mathrm{MS}$ \\
\hline bornyl-acetate & 1288 & 1.42 & 1.41 & 1.03 & RT GC MS \\
\hline carvacrol & 1298 & 1.32 & 1.41 & 1.56 & RT GC MS \\
\hline pregeijerene & 1303 & 0.56 & 0.77 & 0.54 & $\mathrm{RT}^{*} \mathrm{MS}$ \\
\hline eugenol & 1366 & 0.16 & 0.20 & 0.12 & $\mathrm{RT}^{*} \mathrm{MS}$ \\
\hline$\alpha$-copaene & 1391 & 0.25 & 0.26 & 0.19 & $\mathrm{RT}^{*} \mathrm{MS}$ \\
\hline$\beta$-bourbonene & 1400 & 0.43 & 0.37 & 0.51 & $\mathrm{RT}^{*} \mathrm{MS}$ \\
\hline$\beta$-cubenene & 1404 & 0.52 & 0.46 & 0.72 & $\mathrm{RT}^{*} \mathrm{MS}$ \\
\hline$\alpha$-gurjunene & 1408 & 3.09 & 3.43 & 3.37 & $\mathrm{RT}^{*} \mathrm{MS}$ \\
\hline$\beta$-caryophyllene & 1440 & 13.20 & 14.34 & 17.99 & RT GC MS \\
\hline (Z)- $\beta$-farnesene & 1446 & 4.28 & 4.71 & 5.12 & $\mathrm{RT}^{*} \mathrm{MS}$ \\
\hline$\alpha$-humulene & 1452 & 2.04 & 1.90 & 2.62 & RT GC MS \\
\hline (E)- $\beta$-farnesene & 1456 & 3.71 & 4.37 & 5.08 & $\mathrm{RT}^{*} \mathrm{MS}$ \\
\hline$\gamma$-muurolene & 1494 & 5.59 & 5.56 & 6.26 & $\mathrm{RT}^{*} \mathrm{MS}$ \\
\hline germacrene-D & 1503 & 6.79 & 8.56 & 9.05 & $\mathrm{RT}^{*} \mathrm{MS}$ \\
\hline$\beta$-ionone & 1514 & 1.14 & 0.15 & 0.90 & $\mathrm{RT}^{*} \mathrm{MS}$ \\
\hline $\begin{array}{l}\text { bicyclogermacre } \\
\text { ne }\end{array}$ & 1517 & 7.63 & 6.42 & 9.80 & $\mathrm{RT}^{*} \mathrm{MS}$ \\
\hline$\alpha$-muurolene & 1526 & 0.14 & 0.19 & 0.12 & $\mathrm{RT}^{*} \mathrm{MS}$ \\
\hline$\gamma$-cadinene & 1533 & - & 0.10 & 0.10 & $\mathrm{RT}^{*} \mathrm{MS}$ \\
\hline$\delta$-cadinene & 1540 & 1.33 & 1.61 & 1.66 & $\mathrm{RT}^{*} \mathrm{MS}$ \\
\hline nerolidol & 1570 & 0.51 & 0.62 & 0.56 & $\mathrm{RT}^{*} \mathrm{MS}$ \\
\hline$\alpha$-cadinene & 1582 & 0.10 & - & 0.12 & $\mathrm{RT}^{*} \mathrm{MS}$ \\
\hline spathulenol & 1601 & 5.18 & 5.68 & 3.76 & $\mathrm{RT}^{*} \mathrm{MS}$ \\
\hline $\begin{array}{l}\text { caryophyllene } \\
\text { oxide }\end{array}$ & 1610 & 4.23 & 3.73 & 4.98 & $\mathrm{RT}^{*} \mathrm{MS}$ \\
\hline viridiflorol & 1618 & 0.78 & 0.76 & 0.80 & $\mathrm{RT}^{*} \mathrm{MS}$ \\
\hline octadecane & 1799 & 0.14 & 0.28 & 0.32 & $\mathrm{RT}^{*} \mathrm{MS}$ \\
\hline nonadecane & 1900 & 0.10 & 0.11 & 0.10 & $\mathrm{RT}^{*} \mathrm{MS}$ \\
\hline undecane & 1948 & - & - & 0.65 & $\mathrm{RT}^{*} \mathrm{MS}$ \\
\hline dodecane & 1956 & 1.28 & 1.36 & 0.26 & $\mathrm{RT}^{*} \mathrm{MS}$ \\
\hline palmitic acid & 1962 & 1.35 & 1.04 & 1.13 & $\mathrm{RT}^{*} \mathrm{MS}$ \\
\hline heneicosane & 2100 & 0.32 & 0.29 & 0.26 & $\mathrm{RT}^{*} \mathrm{MS}$ \\
\hline tricosane & 2299 & 0.72 & 0.66 & 0.70 & $\mathrm{RT}^{*} \mathrm{MS}$ \\
\hline
\end{tabular}


Table 1. Cont.

\begin{tabular}{|c|c|c|c|}
\hline Total identified & 83.66 & 87.60 & 96.15 \\
\hline Monoterpene hydrocarbons & 3.20 & 3.37 & 3.63 \\
\hline Oxygenated monoterpenes & 5.20 & 5.27 & 6.25 \\
\hline Aromatic oxygenated monoterpenes & 1.48 & 1.61 & 1.68 \\
\hline Sesquiterpene hydrocarbons & 49.10 & 52.28 & 62.71 \\
\hline Oxygenated sesquiterpenes & 11.84 & 10.94 & 11.00 \\
\hline Aliphatic compounds & 12.84 & 14.13 & 10.88 \\
\hline
\end{tabular}

Table 1 lists the chemical components of the investigated essential oils. The total number of chemical constituents identified in essential oils was 44 for M. peregrinum from Senta (No.3), 42 for M. peregrinum from Novi Knezevac (No.2) and 41 for M. peregrinum from Rimski Sanac (No.1), representing $96.15 \%, 87.60 \%$ and $83.66 \%$ of the total oil contents, respectively. The main constituents of the essential oil of $M$. peregrinum from all locations were sesquiterpene hydrocarbons ( $\beta$-caryophyllene, bicyclogermacrene and germacrene-D). Besides sesquiterpene hydrocarbons, oxygenated sesquiterpenes (spathulenol and caryophyllene oxide) are also present in relevant quantities. However, we must point out that the amounts of these components in essential oil from different localities are very different. Essential oil obtain from plant collected in Senta (No.3) is the richest of sesquiterpene hydrocarbons (62.71\%), while oxygenated sesquiterpenes are most represented $(11.84 \%)$ in essential oil from plants collected in the Rimski Sanac (No.1) area

Earlier data pertaining to $M$. peregrinum essential oil point out the persistence of two chemotypes, Greek (containing $\beta$-phellandrene, epi-bicyclosesquiphellandrene and bicyclogermacrene as major compounds, together with absence of monoterpene hydrocarbons) [9], and Central Europe, characterized by a high amount of $\beta$-caryophyllene and its oxide, bicyclogermacrene and germacrene-D [10]. The investigated essential oil, obtained from the plant material from the Pannonian plane, has a specific chemical composition and could be categorized by a chemotype which belongs to Central Europe. Also, the three populations of investigated $M$. peregrinum seem to have the same chemotype, as there are many similarities in chemical composition between the three oils, although in some cases the amounts of the corresponding components is different.

The antioxidant potential of $M$. peregrinum essential oil and pure compounds can be evaluated using numerous assays. The first step in these examinations is the screening of the potential activity by different in vitro tests. Each of those is based on one feature of the antioxidant activity, such as the ability of scavenging free radicals, the inhibition of lipid peroxidation, the chelating of transition metal ions (TMI), etc. However, in order to get relevant data, a single method for testing antioxidant activities of plant products is not recommended due to their complex composition [21]. Therefore, the antioxidant activity of the tested essential oil has been evaluated in a series of in vitro tests. Results of antiradical activity of $M$. peregrinum essential oil on the content of $\mathrm{DPPH}, \mathrm{O}_{2}{ }^{--}$and $\mathrm{NO}$ radicals are given in Table 2. 
Table 2. $\mathrm{IC}_{50}$ values $(\mu \mathrm{g} / \mathrm{mL})$ of the neutralization of $\mathrm{DPPH}^{\bullet}, \mathrm{NO}^{\bullet}$ and $\mathrm{O}_{2}{ }^{\bullet-}$ radicals with Marrubium peregrinum essential oil and BHT (as a positive control).

\begin{tabular}{|c|c|c|c|}
\hline & & $\mathbf{I C}_{\mathbf{5 0}}(\boldsymbol{\mu g} \mathbf{g} \mathbf{m L})$ & \\
\hline Source & DPPH radical & $\mathbf{O}_{\mathbf{2}}^{{ }^{-}}$radical & NO radical \\
\hline M. peregrinum (No. 1) & 13.48 & 11.68 & 11.87 \\
\hline M. peregrinum (No. 2) & 13.41 & 16.41 & 13.12 \\
\hline M. peregrinum (No. 3) & 11.69 & 10.82 & 8.81 \\
\hline BHT & 14.31 & 10.46 & 8.63 \\
\hline
\end{tabular}

In the DPPH assay, the ability of the investigated essential oils to act as donors of hydrogen atoms or electrons in transformation of $\mathrm{DPPH}^{\bullet}$ into its reduced form DPPH-H was investigated (Table 2). All of the assessed essential oils were able to reduce the stable, purple-colored radical DPPH to yellowcolored DPPH-H reaching $50 \%$ of reduction with $\mathrm{IC}_{50}$ values as follows: $13.48 \mu \mathrm{g} / \mathrm{mL}$ for $M$. peregrinum (Rimski sanac; No.1), $13.41 \mu \mathrm{g} / \mathrm{mL}$ for $M$. peregrinum (Novi Knezevac; No.2), and $11.69 \mu \mathrm{g} / \mathrm{mL}$ for $M$. peregrinum (Senta; No.3). Comparison of the DPPH scavenging activity of the investigated essential oils with those expressed by tert-butylated hydroxytoluene (BHT) $(14.31 \mu \mathrm{g} / \mathrm{mL})$ showed that all of the examined essential oils expressed stronger antioxidant effects. The best effect of the neutralization of DPPH radicals exhibited the essential oil collected from the Senta locality.

In the $\mathrm{O}_{2}^{-\bullet}$ assay, the ability of essential oil to scavenge superoxide anion radical, was examined (Table 2). On the basis of the results obtained for the values of investigated system it can be seen that the greatest ability to neutralize superoxide anion radical has essential oil from the Senta locality $\left(\mathrm{IC}_{50}=10.82 \mu \mathrm{g} / \mathrm{mL}\right)$ and this ability is a bit weaker compared to the one $\left(\mathrm{IC}_{50}=10.46 \mu \mathrm{g} / \mathrm{mL}\right)$ exhibited by the synthetic antioxidant tert-butylated hydroxytoluene (BHT). Similar results were obtained examining the neutralization of NO radical. Again, essential oil from the Senta locality (No. 3) exhibited the strongest inhibitory effect, as the $\mathrm{IC}_{50}$ value was achieved at the lowest concentration $\left(\mathrm{IC}_{50}=8.81 \mu \mathrm{g} / \mathrm{mL}\right)$. Inhibition of NO radicals with ether oil of $M$. Peregrinum is very significant, having in mind the ability to neutralize the superoxide anion radicals as well. Essential oil of $M$. peregrinum from Senta is especially suited in this process since it neutralizes both superoxide anion radical and NO radical. Obtained results could be explained partially by the presence of a higher amount of compounds responsible for this activity, such as sesquiterpene hydrocarbons (first $\beta$-caryophyllene) recorded in the $M$. peregrinum essential oil from Senta (Table 1).

Table 3. DPPH Scavenging Active Compounds Identified by the TLC Dot-Blot Technique.

\begin{tabular}{lll}
\hline Source & Compound & Rf values \\
\hline M. peregrinum & carvacrol & 0.62 \\
& $\alpha$ - and $\beta$-thujone & $0.64-0.67$ \\
& bornyl acetate & 0.69 \\
& mixture of mono and sesquiterpene hydrocarbons & 0.97 \\
\hline
\end{tabular}

The comparison of control TLC analysis with the results of GCMS (Table 1) and TLC-DPPH methods accomplished the identification of the constituents most responsible for RSC. For the neutralization of $\mathrm{DPPH}^{\bullet}$ radicals, the most responsible compounds were the oxygenated monoterpenes ( $\alpha$ - and $\beta$-thujone, and bornyl acetate) and the mixture of mono- and sesquiterpene hydrocarbons (Table 3). Although found in a small amount in the essential oil of $M$. peregrinum, carvacrol (Table 1) exhibited notable scavenging activity, too. The mono- and sesquiterpene hydrocarbons showed 
considerable overlap when hexane is used, Therefore, in future experiments, some other more suitable should be used. These findings are correlate with the earlier published data on the antioxidant activities of the essential oil and selected essential oil components [22-25]. The obtained results also confirm the previously published data on stronger antioxidant activity of carvacrol as compared to the thymol [4].

The hydroxyl RSC of the examined essential oil (Figure 1) was measured by the deoxyribose assay. Hydroxyl radicals formed in Fenton reaction were detected by their ability to degrade 2-deoxy-Dribose into fragments that on heating with $\mathrm{TBA}$ at low $\mathrm{pH}$, form a pink adduct. However, this feature of the antioxidant activity of investigated essential oils has not been investigated yet.

Figure 1. Inhibition of degradation of 2-deoxyribose by essential oils of $M$. peregrinum from three different locations, and BHT (as a positive control). The essential oils and BHT were diluted in $n$-hexane (the solvent expressed no antioxidant activity) in the deoxyribose assay.

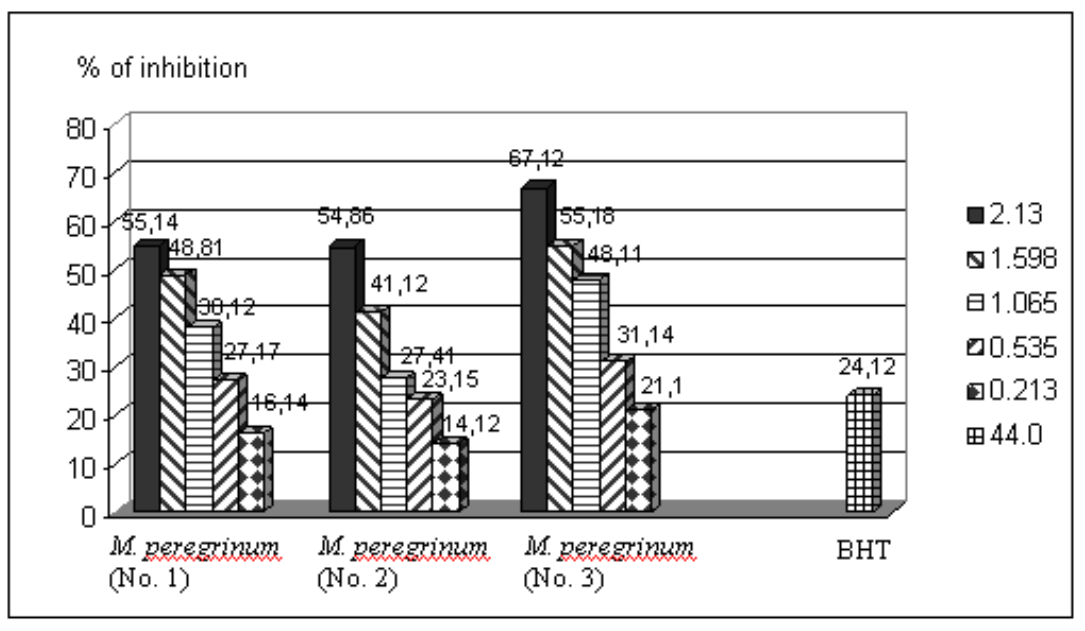

Generally, the examined essential oils from all three locations, except those at the lowest concentration $(0.213 \mu \mathrm{g} / \mathrm{mL})$, inhibited the degradation of deoxyribose more than BHT $(24.12 \%)$, used as a positive control. The highest activity was shown by the essential oil of $M$. peregrinum from Senta locality (No.3), especially in concentration of $2.130 \mu \mathrm{g} / \mathrm{mL}(67.12 \%)$ and $1.598 \mu \mathrm{g} / \mathrm{mL}(55.18 \%)$. The antioxidant activities of all three essential oils were dose dependent. The results confirm the data found in the literature on which it is known that the essential oils of Lamiaceae family, which includes $M$. peregrinum, proved as a great "scavengers" of $\mathrm{OH}$ radicals. Probably, monoterpene ketones are responsible for this effect [5].

Results of activities of XOD with $M$. peregrinum essential oil are given in Table 4. Based on the shown results, it can be seen that only the essential oil from Senta (No.3) expressed stronger protective effect than BHT $(19.23 \mu \mathrm{g} / \mathrm{mL})$. In addition, it was found that the increase of concentration of essential oil reduce the uric acid content and the content of $\mathrm{O}_{2}^{-\bullet}$. This is expected because inhibition of the enzyme XOD, inhibits the creation of $\mathrm{O}_{2}^{-\bullet}$. 
Table 4. $\mathrm{IC}_{50}$ values $(\mu \mathrm{g} / \mathrm{mL})$ of the activities of XOD with Marrubium peregrinum essential oil and and BHT (as a positive control). The essential oils and BHT were diluted in $n$-hexane (the solvent expressed no antioxidant activity) in the XOD assay.

\begin{tabular}{|c|c|c|c|c|}
\hline & & \multicolumn{2}{|c|}{ IC $_{\mathbf{5 0}}(\mu \mathrm{g} / \mathbf{m L})$} & \\
\hline Source & $\begin{array}{c}\text { M. peregrinum } \\
\text { (No. 1) }\end{array}$ & $\begin{array}{c}\text { M. peregrinum } \\
\text { (No. 2) }\end{array}$ & $\begin{array}{c}\text { M. peregrinum } \\
\text { (No. 3) }\end{array}$ & BHT \\
\hline XOD & 21.56 & 23.43 & 17.63 & 19.23 \\
\hline
\end{tabular}

However, if we correlate the content of uric acid and $\mathrm{O}_{2}^{-\bullet}$, we can observe that the values of production of superoxide are below than values of uric acid in the case of all essential oils. This means that the compounds present in the essential oils, in addition to inhibition of XOD skills, possess the ability to neutralize $\mathrm{O}_{2}^{-\bullet}$. As such, the essential oils from tested plant species may contain compounds that would be more effective in the treatment of gout from the widely used allopurinol, which has only the effect of XOD without additional ability to neutralize $\mathrm{O}_{2}^{-\bullet}$ [26]. The protective effects on lipid peroxidation (LP) of essential oils have been evaluated using the $\mathrm{Fe}^{2+}$ /ascorbate system of induction, by the TBA-assay (Figure 2).

Figure 2. Inhibition of $\mathrm{LP}$ in $\mathrm{Fe}^{2+}$ /ascorbate system of induction by essential oils of $M$. peregrinum from three different locations, and BHT (as a positive control). The essential oils and BHT were diluted in $n$-hexane (the solvent expressed no antioxidant activity) in the XOD assay.

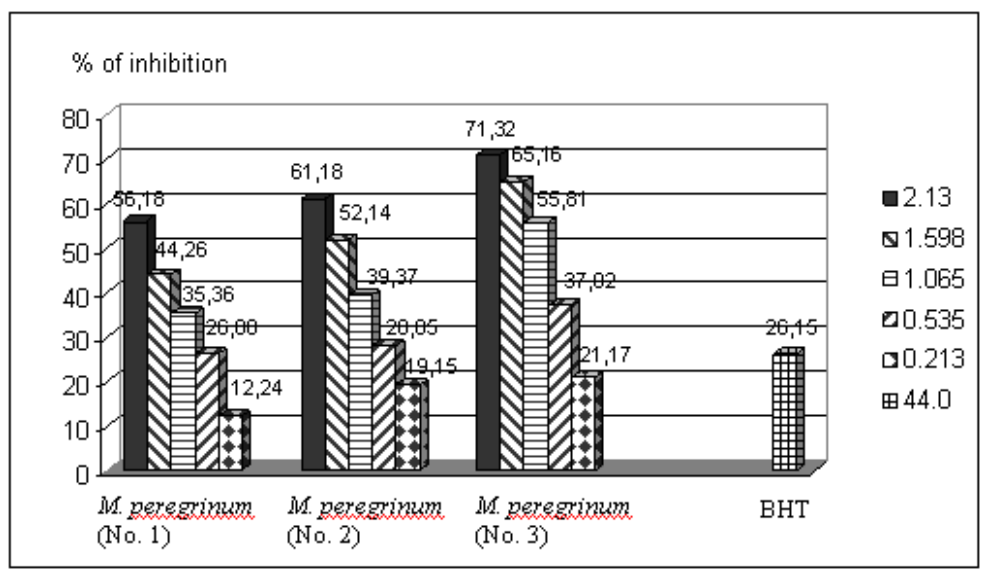

Inhibition of LP was determined by measuring the formation of secondary components (mainly MDA) of the oxidative stress, using liposomes as an oxidizable substrate. In general, the examined essential oils expressed strong antioxidant capacity. The largest inhibitory activity, again, was exhibited by essential oil from plant collected at Senta locality (No.3). Solutions of all concentrations, except the most diluted $(0.213 \mu \mathrm{g} / \mathrm{mL}$ ), have exhibited a stronger protective effect (from 37.02 to $71.32 \%$ of inhibition of LP) than BHT (26.15\%). The other two essential oils [from Rimski Sanac (No.1) and Novi Knezevac (No.2)], at higher concentration (from 1.065 to $2.130 \mu \mathrm{g} / \mathrm{mL}$ ), have also exhibited more intense protective effects than BHT. 


\section{Experimental}

\subsection{General}

Plant material was collected in the Spring of 2006 from three different locations [Bačko Gradište Rimski Sanac (No. 1), Novi Knezevac (No. 2) and Senta (No. 3)] in the Vojvodina Province, Republic of Serbia. Voucher specimens: Marrubium peregrinum L. 1753 No 2-2065, Bačko Gradište, Rimski Šanac, UTM34TDR24, det.: Goran Anačkov; No 2-2066, Novi Kneževac-Filić, UTM34TDS30, det.: Goran Anačkov; No 2-2067, Senta, UTM34TDR28, det.: Goran Anačkov, were confirmed and deposited at the Herbarium of the Department of Biology and Ecology (BUNS Herbarium), Faculty of Natural Sciences, University of Novi Sad.

Air-dried plant material was submitted to hydrodistillation according to Eur. Pharm. 4 [27], using nhexane as a collecting solvent. The solvent was removed under vacuum. The oils were dried over anhydrous sodium sulphate and kept at $+4{ }^{\circ} \mathrm{C}$. The quantities of the essential oils were determined gravimetrically.

\subsection{Essential oil analysis}

Qualitative and quantitative analyses of the essential oils were carried out using a Hewlett-Packard (HP, G-1800 A, GCD) gas chromatography-mass spectrometry (GC-MS) system, operating in EI mode at $70 \mathrm{eV}$, equipped with a split-splitless injector $\left(200{ }^{\circ} \mathrm{C}\right)$ and a flame ionization detector $\left(250{ }^{\circ} \mathrm{C}\right)$. Helium was used as a carrier gas $(1 \mathrm{~mL} / \mathrm{min})$, and the capillary columns used were HP-5 MS (30 $\mathrm{m} \mathrm{x}$ $0.25 \mathrm{~mm}$; film thickness, $0.25 \mu \mathrm{m})$. The temperature programs were $60-280{ }^{\circ} \mathrm{C}$ at a rate of $3{ }^{\circ} \mathrm{C} / \mathrm{min}$ and $60-260{ }^{\circ} \mathrm{C}$ at a rate of $3{ }^{\circ} \mathrm{C} / \mathrm{min}$, respectively; split ratio, $1: 10$. The identification of individual compounds was based on comparison of their relative retention times with those of authentic samples (Carl Roth GmbH; Karlsruhe, Germany), by coelution and MS analysis. For the components, mostly sesquiterpenes and aliphatic compounds, for which reference substances were not available, the identification was performed by matching their retention indices and mass spectra with those obtained from authentic samples and/or the NIST/NBS, Wiley Libraries spectra, and literature data [20].

\subsection{In vitro experiments}

Antioxidant properties of $M$. peregrinum essential oil was evaluated measuring the scavenging activity of the examined essential oil on the 2,2-diphenyl-1-picrylhydrazyl (DPPH), super oxide anion $\left(\mathrm{O}_{2}{ }^{--}\right)$, nitric-oxide $(\mathrm{NO})$ and $\mathrm{OH}$ radicals using a Beckman DU 65 spectrophotometer. Activity of XOD and intensity of LPx in liposomes were evaluated using the same unit.

The DPPH assay was performed as described before [28], following the transformation of the DPPH radical to its reduced, neutral form (DPPH-H). The samples (from 2.50 to $25.0 \mu \mathrm{g} / \mathrm{mL}$ ) were mixed with $90 \mu \mathrm{M} \mathrm{DPPH}{ }^{\circ}$ solution $(1 \mathrm{~mL})$ and filled up with $95 \% \mathrm{MeOH}$ to a final volume of $4 \mathrm{~mL}$. The absorbance of the resulting solutions was recorded spectrophotometrically at $515 \mathrm{~nm}$ after $1 \mathrm{~h}$ at room temperature, against the blank (with the same chemicals, except for the sample). The same procedure was repeated with tert-butylated hydroxytoluene (BHT) as a positive control. For each sample five replicates were recorded. The RSC in percent was calculated by following equation: 


$$
\operatorname{RSC}(\%)=100 \times\left(A_{\text {blank }}-A_{\text {sample }} / A_{\text {blank }}\right)
$$

From the obtained RSC values, the IC50 values, which represented the concentrations of the essential oils that caused $50 \%$ neutralization, were determined by linear regression analysis.

Super oxide anion radicals were generated in the system xanthine/xanthine-oxidase, and the quantity of $\mathrm{O}_{2}{ }^{\bullet-}$ was determined by nitrite method [26] with modifications. This system was used also in determination of the level of inhibition of xanthine-oxidase. All solutions and reagents were freshly prepared by dissolution in $0.05 \mathrm{M} \mathrm{KH}_{2} \mathrm{PO}_{4}-\mathrm{K}_{2} \mathrm{HPO}_{4}$ phosphate buffer ( $\mathrm{pH} 7.4$ ). The samples of the essential oil of $M$. peregrinum were investigated in different concentrations (from 2.50 to $25.00 \mu \mathrm{g} / \mathrm{mL}$ ). The absorbance of the resulting solutions was recorded spectrophotometrically at 550 $\mathrm{nm}$ after $30 \mathrm{~min}$ at room temperature, against the blank (with the same chemicals, except for the xanthine-oxidase). The same procedure was repeated with BHT as a positive control. For each sample five replicates were recorded.

Production of $\mathrm{NO}^{\bullet}$ radicals was determined spectrophotometrically. $\mathrm{NO}^{\bullet}$ radical generated from sodium-nitropruside (SNP) reacts with oxygen in water solution at a physiological $\mathrm{pH}$ to give nitrite ions. Concentration of nitrite anions was determined using Griess reagent [29]. At room temperature nitrite ions react with Griess reagent and form purple complex. The samples of the essential oil of $M$. peregrinum were investigated in different concentrations (from 2.50 to $25.00 \mu \mathrm{g} / \mathrm{mL}$ ). The intensity of color, which is the function of the nitrite concentrations, was measured spectrophotometrically $(\lambda=546 \mathrm{~nm})$. The absorbance of the resulting solutions and the blank (with the same chemicals, except for the sample) were recorded. For each sample, five replicates were recorded. The RSC in percent was calculated by following equation:

$$
\operatorname{RSC}(\%)=100 \times\left(A_{\text {blank }}-A_{\text {sample }} / A_{\text {blank }}\right)
$$

From the obtained RSC values, the IC50 values, which represented the concentrations of the essential oils that caused $50 \%$ neutralization, were determined by linear regression analysis.

Scavenging capacity of the essential oils for hydroxyl radicals was determined by monitoring the chemical degradation of 2-deoxy-D-ribose [30]. The reaction was initiated by hydroxyl radicals obtained in Fenton's reaction [31], which yields products that react with thiobarbituric acid (TBA test). The obtained products, among which malondialdehyde (MDA) is the most important, are determined by a spectrophotometric method at $532 \mathrm{~nm}$ (deleted). The degradation products are the 2-thiobarbituric acid (TBA) reactive substances, which could be determined spectrophotometrically at $532 \mathrm{~nm}$. All solutions and reagents were freshly prepared by dissolution in $0.05 \mathrm{M} \mathrm{KH}_{2} \mathrm{PO}_{4}-\mathrm{K}_{2} \mathrm{HPO}_{4}$ phosphate buffer ( $\mathrm{pH}$ 7.4). For the experiment, five concentrations of essential oils were prepared: pure essential oil $(2.130 \mu \mathrm{g} / \mathrm{mL}), 75 \%(1.598 \mu \mathrm{g} / \mathrm{mL}), 50 \%(1.065 \mu \mathrm{g} / \mathrm{mL}), 25 \%(0.535 \mu \mathrm{g} / \mathrm{mL})$ and $10 \%$ $(0.213 \mu \mathrm{g} / \mathrm{mL})$ solution in $n$-hexane. In a test tube, pure essential oils and $75 \% .50 \%, 25 \%$ or $10 \%$ solution in $n$-hexane $(10 \mu \mathrm{L})$ with $\mathrm{H}_{2} \mathrm{O}_{2}(0.125 \mathrm{~mL}), \mathrm{FeSO}_{4}(0.125 \mathrm{~mL})$ and 2-deoxy-D-ribose $(0.125 \mathrm{~mL})$ were mixed and filled up with $0.05 \mathrm{M} \mathrm{PB}, \mathrm{pH} 7.4$, to a volume of $3 \mathrm{~mL}$. After an incubation period of $1 \mathrm{~h}$ at $37^{\circ} \mathrm{C}$, the extent of deoxyribose degradation was measured by the TBA reaction. An amount of TBA reagent $\left[1.5 \mathrm{~mL}, 10.4 \mathrm{~mL}\right.$ of $10 \% \mathrm{HClO}_{4}, 3 \mathrm{~g}$ of TBA, and $120 \mathrm{~g}$ of $20 \%$ trichloroacetic acid] and $0.2 \mathrm{~mL}$ of $0.1 \mathrm{M}$ ethylenediaminetetraacetic acid (EDTA) were added to the reaction mixture, and the tubes were heated at $100{ }^{\circ} \mathrm{C}$ for $20 \mathrm{~min}$. After the mixtures were cooled, the absorbance was read against a blank (containing buffer solution instead sample) at $532 \mathrm{~nm}$. A control 
with $n$-hexane instead of sample was also tested and expressed no activity. Five replicates were recorded for each sample. A $0.1 \mathrm{M}$ concetration of BHT $(44.0 \mu \mathrm{g} / \mathrm{mL})$ was used as a positive control.

The absorbance reading at the end of the experiment was used for the calculation of the percentage inhibition of deoxyribose degradation by the essential oil:

$$
I(\%)=100 \times\left(A_{\text {blank }}-A_{\text {sample }} / A_{\text {blank }}\right)
$$

The extent of LP was determined by measuring the color of the adduct produced in the reaction between 2-thiobarbituric acid (TBA) and malondialdehyde (MDA), as an oxidation product in the peroxidation of membrane lipids, by the TBA assay [3,32,33]. The commercial preparation of liposomes 'PRO-LIPO S' (Lucas-Meyer) $\mathrm{pH}=5-7$ was used as a model system of biological membranes. The liposomes, 225-250 $\mathrm{nm}$ in diameter, were obtained by dissolving the commercial preparation in demineralized water (1:10), in an ultrasonic bath. Five concentrations of essential oils were prepared for the experiment: pure essential oil $(2.13 \mu \mathrm{g} / \mathrm{mL}), 75 \%(1.598 \mu \mathrm{g} / \mathrm{mL}), 50 \%$ $(1.065 \mu \mathrm{g} / \mathrm{mL}), 25 \%(0.535 \mu \mathrm{g} / \mathrm{mL})$ or $10 \%(0213 \mu \mathrm{g} / \mathrm{mL})$ solution in $\mathrm{n}$-hexane. The content of the MDA (TBARS) was determined by measuring the absorbance of adduct at $532 \mathrm{~nm}$. In a test tube, a suspension of liposomes $(50 \mu \mathrm{L})$ was incubated with $0.01 \mathrm{M}$ FeSO4 $(20 \mu \mathrm{L}), 0.01 \mathrm{M}$ ascorbic acid $(20 \mu \mathrm{L})$, and essential oil samples $(10 \mu \mathrm{L})$ in $0.05 \mathrm{M} \mathrm{KH}_{2} \mathrm{PO}_{4}-\mathrm{K}_{2} \mathrm{HPO}_{4}$ buffer $(2.90 \mathrm{~mL}$, pH 7.4, $3 \mathrm{~mL}$ final solution). Samples were incubated at $37^{\circ} \mathrm{C}$ for $1 \mathrm{~h}$. LP was terminated using the reaction with $1.5 \mathrm{~mL}$ of TBA reagent and 0.2 or $0.1 \mathrm{~mL}$ of EDTA, heated at $100{ }^{\circ} \mathrm{C}$ for $20 \mathrm{~min}$. After precipitated proteins were cooled and centrifuged (4000 rpm for $10 \mathrm{~min}$ ), the content of the MDA (TBARS) was determined by measuring the absorbance of adduct at $532 \mathrm{~nm}$. Analyses were compared with the commercial synthetic antioxidant BHT ( $0.1 \mathrm{M}$ stock solution, concentration $44.0 \mu \mathrm{g} / \mathrm{mL})$ as a positive control. Five replicates were performed for each sample. The control with n-hexane was also analyzed.

The percentage of LP inhibition was calculated by the following equation:

$$
I(\%)=\left(A_{0}-A_{1}\right) / A_{0} \times 100
$$

where $A_{0}$ is the absorbance of the control reaction (full reaction, without the test compound) and $A_{1}$ is the absorbance in the presence of the inhibitor.

\subsection{Rapid screening for scavenging compounds of essential oils}

For fast screening of essential oil compounds on RSC, the dot-blot test on thin-layer chromatography (TLC) silica gel $\mathrm{F}_{254}$ aluminium plates stained with the free radical DPPH' was used [5]. An appropriate amount of pure essential oil $(5 \mu \mathrm{L})$ was placed on a silica gel plate and eluted with benzene:ethyl acetate (95:5). After drying, the plates were sprayed with a $0.4 \mathrm{mM}$ solution of $\mathrm{DPPH}^{*}$ in methanol, using a Desaga Spray Gun. Sprayed plates gave a purple background with yellow spots at the location of those compounds that possessed high RSC. Essential oil compounds responsible for scavenging activity were identified comparing the DPPH-TLC chromatogram with the control treated with vanillin-sulphuric acid spray reagent. 


\subsection{Chemicals}

Thiobarbituric acid (TBA), xanthine, xanthine-oxidase, ethylenediaminetetraacetic acid (EDTA), 2,2-diphenyl-1-picrylhydrazyl (DPPH) and trichloroacetic acid were obtained from Sigma Chemicals, (St. Louis, MO, USA). 2-Deoxy-D-ribose was purchased from Aldrich. $N$-(1-naphthyl)ethylenediamine dihydrochloride (NEDA), silica gel $\mathrm{F}_{254}$ aluminium plates and $n$-hexane were obtained from Merck (Darmstadt, Germany). tert-butylated hydroxytoluene was obtained from Fluka, AG (Buchs, Switzerland). The commercial preparation of liposomes "PRO-LIPO S" was purchased from Lucas-Meyer (Hamburg, Germany). All chemicals used were of analytical grade.

\section{Conclusions}

In conclusion, the results of in vitro assays of the investigated essential oils, expressed significant RSC and protective effects on LP, which was found to be correlated to different compounds, depending on the system of examination. In particular, the investigated essential oils exhibited high RSC against DPPH, $\mathrm{O}_{2}^{-\bullet}$ and NO radical, which was found to correlate with the content of oxygenated monoterpenes ( $\alpha$ - and $\beta$-thujone, and bornyl acetate) and the mixture of mono- and sesquiterpene hydrocarbons sesquiterpene hydrocarbons (primarily $\beta$-caryophyllene). Also, a very strong protective activity of the essential oils (especially the essential oil from Senta locality, No.3) in lipid peroxidation processes, especially against hydroxyl radicals formed in the Fenton reaction, was recorded. These results indicate that essential oils could serve not only as flavorings but also as safe antioxidants and antiseptic supplements in preventing deterioration of foodstuffs and beverages and pharmaceuticals. Also, consumption of food produced with natural essential oils or aromatic plant extracts (functional foods) is expected to prevent the risk of free radical dependent diseases. The use of investigated essential oils and spices could be useful not only in food and cosmetics production but also as important functional food in the prevention and treatment of various human diseases.

\section{Acknowledgements}

This work was supported by the Provincial Secretariat for Science and Technological Development, Autonomous Province of Vojvodina, Republic of Serbia (Project No. 114-451-02081/2009-03). Also, we would like to send our gratitude to Goran Anackov, Herbarium of the Department of Biology and Ecology (BUNS Herbarium), Faculty of Natural Sciences, University of Novi Sad.

\section{References and Notes}

1. Blumenthal, M. The Complete German Commission E Monographs; American Botanical Council: Austin, TX, USA, 1998; pp. 218-219.

2. Bruneton, J. Pharmacognosy, Phytochemistry, Medicinal Plants, 2nd ed.; Intercept Ltd.: London, UK, 1999; pp. 12-14.

3. Afanas'ev, A.; Dorozhko, I.; Brodski, V.; Kostyk, A.; Potapovich, I. Chelating and free radical scavenging mechanism of inhibitory action of rutin and quercetin in lipid peroxidation. Biochem. Pharmacol. 1989, 38, 1763-1769. 
4. Ruberto, G.; Baratta, T. Antioxidant activity of selected essential oil components in two lipid model systems. Food Chem. 2000, 69, 167-174.

5. Mimica-Dukic, N.; Bozin, B.; Sokovic, M.; Mihajlovic, B.; Matavulj, M. Antimicrobial and antioxidant activities of three Mentha species essential oils. Planta Med. 2003, 69, 413-419.

6. Arora, A.; Nair, G.M.; Strasburg, M.G. Structure-activity relationships for antioxidant activities of a series of flavonoids in a liposomal system. Free Radical Biol. Med. 1998, 24, 1355-1363.

7. Cantino, P.D.; Harley, R.M.; Wagstaff, S.J. Genera of Labiatae: status and classification. In Advances in Labiate Science; Harley, R.M., Reynolds, T., Eds.; Kew: Royal Botanic Gardens, London, UK, 1992; pp. 511-522.

8. Demirci, B.; Baser, H.C.; Kirimer, N. Composition of the essential oil of Marrubium bourgaei ssp. caricum P.H. Davis. J. Essent. Oil Res. 2004, 16, 133-134.

9. Lazari, D.M.; Skaltsa, H.D.; Constantinidis, T. Essential oils of Marrubium velutinum Sm. and Marrubium peregrinum L., growing wild in Greece. Flavour Frag. J. 1999, 14, 290-292.

10. Nagy, M.; Svajdlenka, E. Comparison of essential oils from Marrubium vulgare L. and $M$. peregrinum L. J. Essent. Oils Res. 1998, 10, 585-587.

11. Sahpaz, S.; Hennebelle, T.; Bailleul, F. Marruboside, a new phenylethanoid glycoside from Marrubium vulgare L. Nat. Prod.Lett. 2002, 16, 195-199.

12. Nagy, M.; Gergel, D.; Grancai, D.; Novomesky, P.; Ubik, K. Antilipoperoxidative activity of some phenolic constituents from Marrubium peregrinum L. Farm. Obz. 1996, 65, 283-285.

13. Gruenwald, J.; Brendler, T.; Jaenicke, C. PDRc for Herbal Medicines; Jaenicke, C., Ed.; Medical Economics Co: NewYork, NY, USA, 2000; pp. 271-275, 719-725.

14. Salei, L.A.; Popa, D.P.; Lazurēvskii, G.V. Diterpenoids from Marrubium peregrinum L. Chem. Nat. Comp. 1967, 2, 200-201.

15. Telek, E.; Toth, L.; Botz, L.; Mathe, I. Chemical tests with Marrubium species. Official data on Marrubii herba Pharmacopoeia Hungarica VII 1997. Acta Pharm. Hung. 1997, 67, 31-37.

16. El Bardai, S.; Lyoussi, B.; Wibo, M.; Morel, N. Pharmacological evidence of hypotensive activity of Marrubium vulgare and Foeniculum vulgare in spontaneously hypertensive rat. Clin. Exp. Hypertens. 2001, 23, 329-343.

17. Nielsen, S.E.; Young, J.F.; Daneshvar, B.; Lauridsen, S.T.; Knuthsen, P.; Sandström, B.; Dragsted, L.O. Effect of parsley (Petroselinum crispum) intake on urinary apigenin excretion, blood antioxidant enzymes and biomarkers for oxidative stress in human subject. J. Nutr. 1999, 81, 447-455.

18. Letchamo, W.; Gosselin, A.; Holzl, J. Growth and essential oils content of Angelica archangelica as influenced by light intensity and growing media. J. Essent. Oils Res. 1995, 7, 497-504.

19. Bernard, C.; Clair, G. Essential oils of three Angelica L. species growing in France. Part I. Root oils. J. Essent. Oils Res. 1997, 9, 289-294.

20. Adams, R.P. Identification of Essential Oil Components by Gas Chromatography/Mass Spectroscopy; Allured Publishing Corp.: Carol Stream, IL, USA, 1995.

21. Nuutila, A.M.; Puupponen-Pimia, R.; Aarni, M.; Oksman-Caldentey, K.M. Comparison of antioxidant activities of onion and garlic extracts by inhibition of lipid peroxidation and radical scavenging activity. Food Chem. 2003, 81, 485-493. 
22. Lagouri, V.; Boskou, D. Screening for antioxidant activity of essential oils obtained from spices. In Food FlaVours: Generation, Analysis and Process Influence; Charalambous, G., Ed.; Elsevier Science B.V.: Tokyo, Japan, 1995; pp. 969-879.

23. Milos, M.; Mastelic, J.; Jerkovic, I. Chemical composition and antioxidant effect of glycosidally bound volatile compounds from oregano (Origanum Vulgare L. ssp. hirtum). Food Chem. 2000, $71,79-83$.

24. Lee, B.M.; Lee, S.K.; Kim, H.S. Inhibition of oxidative DNA damage, 8-OhdG, and carbonyl contents in smokers treated with antioxidants (vitamin $\mathrm{E}$, vitamin $\mathrm{C}, \beta$-carotene and red ginseng). Cancer Lett. 1998, 132, 219-227.

25. Baratta, T.M.; Dorman, D.J.H.; Deans, G.S.; Biondi, D.M.; Ruberto, G. Chemical composition, antimicrobial and antioxidant activity of laurel, sage, rosemary, oregano and coriander essential oils. J. Essent. Oils Res. 1998, 10, 618-627.

26. Cos, P.; Ying, L.; Callome, M.; Hu, P.; Cimanga, K.; Van Poel, B.; Pieters, L.; Vlietinick, J.; Van den Berghe, D. Structure-activity relationship and classification of flavonoids as inhibitors of Xanthine oxidase and superoxide scavengers. J. Nat. Prod. 1998, 61, 71-76.

27. 1. \& 2. European Directorate for the Quality of Medicines. European Pharmacopeia, 4th ed.; Council of Europe: Strasbourg Cedex, France, 2002; Supplement 4.1.-4.2., pp. 183-184.

28. Espin, J.C.; Soler-Rivas, C.; Wichers, H.J. Characterisation of the total free radical scavenger capacity of vegetable oils and oil fractions using 2,2-diphenyl-1-picrylhydrazyl radical. J. Agric. Food Chem. 2000, 48, 648-656.

29. Green, C.; Wagner, A.; Glogowski, J.; Skipper, I.; Wishnok, S.; Tannenbaum, R. Analysis of nitrat, nitrit and $\left[{ }^{15} \mathrm{~N}\right]$ nitrit in biological fluids. Anal. Biochem. 1982, 126, 131-138.

30. Cheesman, H.; Beavis, A.; Eserbauer, H. Hydroxyl-radical-induced-iron-catalysed degration of 2deoxyribose. Biochem. J. 1988, 252, 649-653.

31. Halliwell, B.; Gutteridge, J.M.C. Free Radicals in Biology and Medicine; Clarendon Press: Oxford, UK, 1986; pp. 183-189.

32. Fukuzawa, K.; Seko, T.; Minami, K.; Terao, J. Dynamics of iron-ascorbate-induced lipid peroxidation in charged and uncharged phospholipid vesicles. Lipids 1993, 28, 497-503.

33. Buege, A.J.; Aust, D.S. Methods in Enzymology; Fleischer, S., Parker, L., Eds.; Academic Press: New York, NY, USA, 1988; pp. 302-310.

Sample Availability: Not available.

(C) 2010 by the authors; licensee MDPI, Basel, Switzerland. This article is an open access article distributed under the terms and conditions of the Creative Commons Attribution license (http://creativecommons.org/licenses/by/3.0/). 